\title{
MORPHOMETRY OF MATA DO AMPARO DAM, ITAMARACÁ ISLAND, PERNAMBUCO, BRAZIL
}

\author{
MORFOMETRIA DO RESERVATÓRIO MATA DO AMPARO, ILHA DE ITAMARACÁ, \\ PERNAMBUCO, BRASIL
}

\author{
William SEVERI \\ Laboratório de Ictiologia / Laboratório de Limnologia. Departamento de Pesca e Aquicultura. Universidade Federal Rural de \\ Pernambuco. Rua Dom Manoel de Medeiros - s/n, Dois Irmãos, Recife, Pernambuco, Brasil. E-mail: wseveri@gmail.com

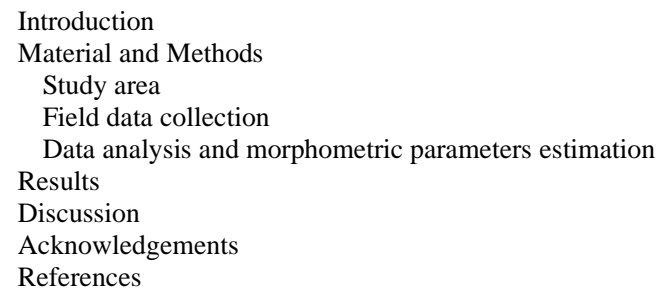

\begin{abstract}
Lake morphology is closely related to the geomorphological process responsible for its origin, and influences the dynamics of most physical, chemical and biological properties of lacustrine environments. Different methodologies and highly accurate equipment have greatly improved the technological capacity for bathymetric mapping in the last decade, but their use has been applied to a limited number of environments in Brazil, owing to their high cost and lack of trained personnel. In the present study, an accessible and low-cost approach was used to characterize the morphometrics of Mata do Amparo Dam, a man-made lake in Itamaracá Island, Pernambuco State, northeastern Brazil. Lake bathymetry with a portable echosounder and GPS was conducted in 372 points, and additional 138 points of lake perimeter were digitalized from a satellite image and later interpolated for generation of a bathymetry chart, 3D views and estimation of volume. The reservoir has a surface area of $0.042 \mathrm{~km}^{2}$, a maximum depth of $6.2 \mathrm{~m}$ and an estimated volume of $0.11 \times 10^{6} \mathrm{~m}^{3}$. The methodology used provided an acceptable estimate of morphometric parameters, and a physical background for future limnological studies on the reservoir.
\end{abstract}

Keywords: bathymetry, morphology, volume.

RESUMO - A morfologia de lagos está intimamente associada ao processo geomorfológico responsável por sua origem, e influencia a dinâmica da maioria das propriedades físicas, químicas e biológicas de ambientes lacustres. Diferentes metodologias e equipamentos altamente precisos têm melhorado a capacidade técnica do mapeamento batimétrico na última década, mas seu uso tem sido aplicado a um número limitado de ambientes no Brasil, devido a seu elevado custo e carência de pessoal treinado. No presente estudo, uma abordagem acessível e de baixo custo foi usada para caracterizar a morfometria do Reservatório Mata do Amparo, um lago artificial na Ilha de Itamaracá, Estado de Pernambuco, nordeste do Brasil. Uma batimetria do lago com ecobatímetro portátil e GPS foi realizada em 372 pontos e 138 pontos adicionais do perímetro foram digitalizados numa imagem de satélite, e posteriormente interpolados para geração de mapa batimétrico, perfis em 3D e estimativa do volume. O reservatório tem área superficial de $0,042 \mathrm{~km}^{2}$, profundidade máxima de 6,2 $\mathrm{m}$ e volume estimado de $0,11 \times 10^{6} \mathrm{~m}^{3}$. A metodologia utilizada forneceu uma estimativa aceitável dos parâmetros morfométricos, sendo um referencial físico para futuros estudos limnológicos no reservatório.

Palavras-chave: batimetria, morfologia, volume.

\section{INTRODUCTION}

Lake morphology is closely related to the geomorphological process responsible for its origin (Wetzel, 2001; Tundisi \& MatsumuraTundisi, 2008), and influences the physical, chemical and biological dynamics of lacustrine environments, including vertical thermal stratification and horizontal circulation, sedimentation, concentration of suspended matter, water retention time, nutrient cycling and trophic state (Johansson et al., 2007). Beyond the geological and climatic events that promoted the formation of lake basins, natural lakes and artificial impoundments are similarly affected by anthropic stress from human activities within their catchment area, which may hamper their ecological integrity and management of water resources (Tundisi \& Matsumura-Tundisi, 2008).

Dams and reservoirs are artificial lentic environments usually constructed for some preconceived purpose, such as energy generation, water stocking for public supply, livestock watering or crop irrigation, being strongly subject to use conflicts resulting from water multiple use, independently from its original purpose (Branco \& Rocha, 1977; Tundisi, 2003).

Studies on lake morphology and morphometric characteristics have long been regarded as essential for better understanding the 
limnological processes (Hutchinson, 1957), mainly lake metabolism and productivity (Wetzel, 2001; Tundisi \& Matsumura-Tundisi, 2008).

In Brazil, pioneer lake morphometry studies aimed at limnological research were conducted in coastal lagoons in Rio de Janeiro State (Azevedo, 1984) and Rio Grande do Sul State (Schwarzbold \& Schäfer, 1984), and in the Doce River Valley lakes, Minas Gerais State (Tundisi \& Musarra, 1986). Further studies were developed in natural and artificial lakes located in other regions of the country, including upland lakes in the Amazon region (Silva et al., 2018), floodplain lakes in the Pantanal Mato-grossense (Fantin-Cruz et al., 2008), and, only more recently, impoundments (açudes) in the dry semiarid northeastern Caatinga (Moura et al., 2015).

Different methodological approaches have been used to characterize the morphological parameters of lakes (Tundisi \& Musarra, 1986 versus Bezerra-Neto et al., 2010), and there has been a great improvement in the technological capacity for bathymetric mapping in the last decade. The use of echosounders combined with differential global positioning systems (DGPS) have provided an accurate mapping coupled with exportation of the data to geographical information system (GIS). However, such tools have been applied to a limited number of lacustrine environments in Brazil, owing to their high cost and lack of trained personnel (BezerraNeto \& Pinto-Coelho, 2008).

The present study aimed at using a simple and low-cost methodology for bathymetry and data acquisition for the physical characterization of a small-sized reservoir, as an accessible tool for limnological studies.

\section{MATERIAL AND METHODS}

\section{Study Area}

Mata do Amparo Dam (Figure 1) is a man-made reservoir supposedly built around 1939-40, for water storage and supply to the Penitenciária (Prison) Agro Industrial São João, formerly Penitenciária Agrícola de Itamaracá established in 1940, located in Itamaracá Island, northern region of Pernambuco State (Santos, 2011). It is located at the headwaters of the Jaguaribe River basin and is

presently inserted in the Mata (Forest) do Amparo Wildlife Refuge.

Mata do Amparo is a natural remnant of the Brazilian Atlantic Forest biome, with an area of 172,9 ha, located ca. $40 \mathrm{~km}$ from the capital Recife. It was established by the Pernambuco State Law n. 13539 of 12 September 2008 (originally established as an Ecological Reserve by the State Law n. 9989 of 13 January 1987).

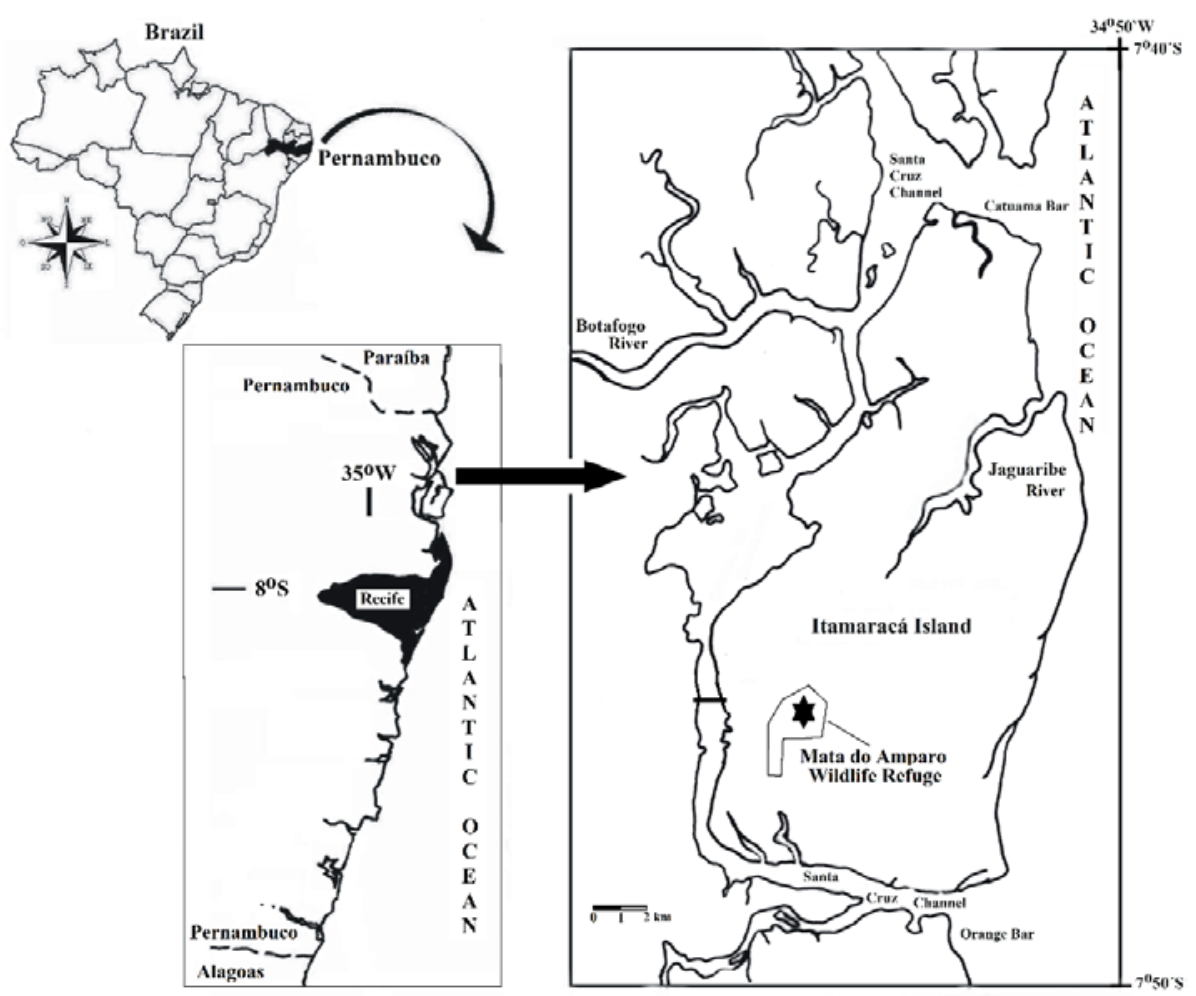

Figure 1- Map of Itamaracá Island, with approximate location (*) of Mata do Amparo Dam, northeastern Brazil. 
The region has a climate of type As' (Köppen, 1931), an average annual rainfall of $1,867 \mathrm{~mm}$, and average air temperatures between 18 and $34^{\circ} \mathrm{C}$. October, November, December, January, February and March correspond to the dry summer season, and April, May, June, July, August and September to the rainy autumn/winter season (CPRM, 2005).

Knowledge about ecological aspects of the forest and the reservoir is lacking. The only available published information about the forest is Pereira et al. (2006), who reported the occurrence of the pilgrim-falcon Falco peregrinus at Mata do Amparo, among the other localities in Pernambuco State where the species has been recorded. No information regarding the reservoir is available in the literature.

\section{Field Data Collection}

Reservoir depth data were obtained with a portable sounder (Speedtech Depthmate SM-5, 200 Khz) along thirteen transects on 20-21 September 2016 (Figure 2A). The coordinates of each point were measured with a GPS Garmin Map 76CSx (WGS84 horizontal datum) and stored for later download using the software Garmin MapSource 6.16.3. Both initial and end points of each transect (as 0 -m depth points) were recorded as additional reference points for perimeter and surface area estimation.

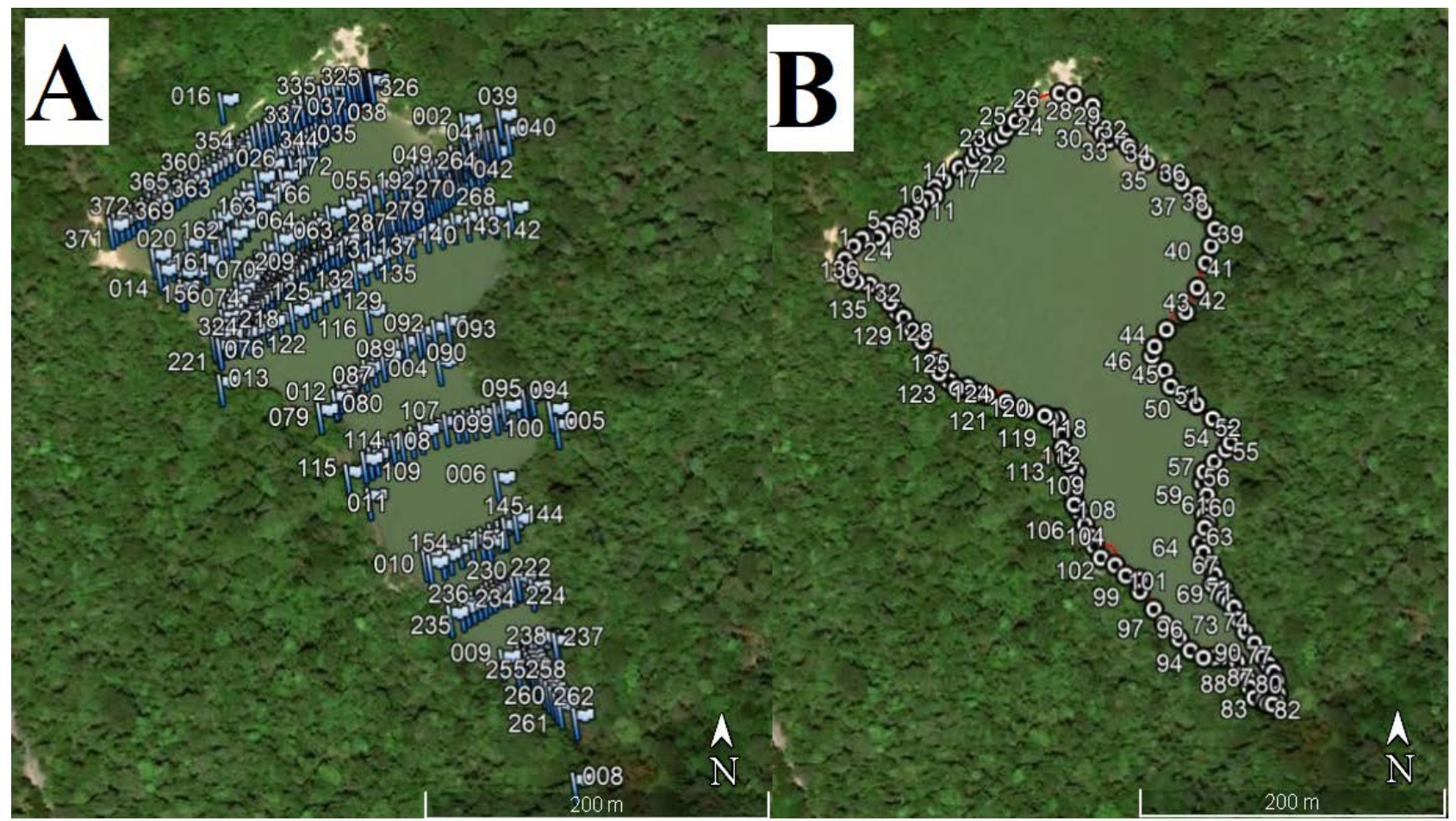

Figure 2 - Satellite view of Mata do Amparo Dam with transects used for bathymetry (A) and points used for the estimation of its perimeter (B). Modified from a Google Earth image.

Data Analysis and Morphometric Parameters Estimation

The reservoir contour was digitalized from a Google Earth image dated from November 2016, along 138 points used for perimeter estimation (Figure 2B), recorded as a Google Earth kml file. Perimeter and transects data were later integrated into a XYZ spreadsheet used to draw the bathymetry chart and 3D views, and calculate corresponding areas at each 1-m depth interval, with the software Surfer 10 (Golden Software, 2011) using the kriging method.

Maximum depth (Zmax) was calculated from field data, whereas perimeter (P), effective length $\left(\mathrm{L}_{\mathrm{e}}\right)$ and maximum effective width $\left(\mathrm{W}_{\mathrm{e}}\right)$ were estimated by direct measurement on the chart. Surface area (A) and areas at each 1-m isobath were used for the estimation of volume (V) and for the hypsographic curves of depth-area and depth volume, according to Wetzel \& Likens (2000). The morphometric parameters mean depth (Z), relative depth $\left(\mathrm{Z}_{\mathrm{r}}\right)$ and shore line development index $\left(\mathrm{D}_{\mathrm{L}}\right)$ followed Wetzel \& Likens (2000), the development volume index $\left(\mathrm{D}_{\mathrm{v}}\right)$ was calculated according to Schäfer (1984), and the mean width according to Wetzel (2001).

\section{RESULTS}

The morphometric survey of Mata do Amparo geographical location and depth, with 0.1-m Dam was conducted with 372 points with known depth accuracy. 
The kriging method was chosen for data interpolation and grid generation as it is regarded as a good estimator in relation to the original points of observation (Bezerra-Neto et al., 2010).

A bathymetric model was generated with 1-m depth isobaths (Figure 3), based on a reservoir elevation of $30 \mathrm{~m}$ above sea level and maximum water level on the date of field sampling. The morphometric information of Mata do Amparo Dam are summarized in Table 1, and corresponding area and volume per depth layer are presented in Table 2 ..



Figure 3 - Bathymetric map of Mata do Amparo Dam, Itamaracá Island, Pernambuco State. Black star indicates the location of maximum depth $(6.2 \mathrm{~m})$.

The 3-D bathymetric model (Figure 4) helps the visualization of Mata do Amparo Dam basin, which reflects the typical shape of a lake formed by the damming of a river valley, represented by the upper stretch of Jaguaribe River.

The depth contours of the reservoir bottom are reasonably uniformly spaced from the margin to the maximum depth, but two main depressions are visible, a larger one closer to the dam from the 3-m isobath to the maximum depth of $6.2 \mathrm{~m}$, and a smaller one on the upper third of the reservoir surface area from the 2-m isobath to a maximum depth of $3.5 \mathrm{~m}$. The hypsographic area-depth and volume-depth curves (Figure 5) revealed that almost $69 \%$ of the total area is below $1.0 \mathrm{~m}$ depth (16\% of total depth), whereas $57 \%$ of total volume is between surface and 2.0 m (32\% of total depth) (Table 2).

Table 1 - Morphometric characteristics of Mata do Amparo Dam, Pernambuco State, Brazil.

\begin{tabular}{lr}
\hline \multicolumn{2}{c}{ Morphometric parameters } \\
\hline Surface area $\left(\mathrm{A}, \mathrm{km}^{2}\right)$ & 0.042 \\
\hline Volume $\left(\mathrm{V}, \mathrm{m}^{3}\right)$ & $0.11 \times 10^{6}$ \\
\hline Shoreline perimeter $(\mathrm{P}, \mathrm{m})$ & $1,215.00$ \\
\hline Maximum effective length $\left(\mathrm{L}_{\mathrm{e}}, \mathrm{m}\right)$ & 399.00 \\
\hline Maximum effective width $\left.\mathrm{W}_{\mathrm{e}}, \mathrm{m}\right)$ & 189.00 \\
\hline Maximum depth $\left(\mathrm{Z}_{\max }, \mathrm{m}\right)$ & 6.20 \\
\hline Mean depth $(\mathrm{Z}, \mathrm{m})$ & 2.57 \\
\hline Z / $\mathrm{Z}_{\max }$ & 0.42 \\
\hline Relative depth $\left(\mathrm{Z}_{\mathrm{r}}, \%\right)$ & 2.68 \\
\hline Mean width $(\mathrm{m})$ & 105.28 \\
\hline Volume development index $\left(\mathrm{D}_{\mathrm{v}}\right)$ & 1.25 \\
\hline Shoreline development index $\left(\mathrm{D}_{\mathrm{s}}\right)$ & 1.67 \\
\hline
\end{tabular}


Table 2 - Area and volume data by strata of Mata do Amparo Dam, Pernambuco State, Brazil.

\begin{tabular}{c|c|c|c|c|c}
\hline Depth (m) & Area $\left.\mathbf{( m}^{\mathbf{2}}\right)$ & Area (\%) & Layer & Volume $\left.\mathbf{( m}^{\mathbf{3}}\right)$ & Volume (\%) \\
\hline 0 & 42007.00 & 100.00 & $0-1$ & 34983.19 & 32.36 \\
\hline 1 & 28883.33 & 68.76 & $1-2$ & 26289.71 & 24.32 \\
\hline 2 & 23780.31 & 56.61 & $2-3$ & 20406.99 & 18.88 \\
\hline 3 & 17314.23 & 41.22 & $3-4$ & 14211.59 & 13.15 \\
\hline 4 & 11749.34 & 27.97 & $4-5$ & 8888.99 & 8.22 \\
\hline 5 & 6308.37 & 15.02 & $5-6$ & 3258.30 & 3.01 \\
\hline 6 & 980.05 & 2.33 & $6-6,2$ & 65.34 & 0.06 \\
\hline 6,2 & 0.00 & 0.00 & Total & 108104.10 & 100.00 \\
\hline
\end{tabular}
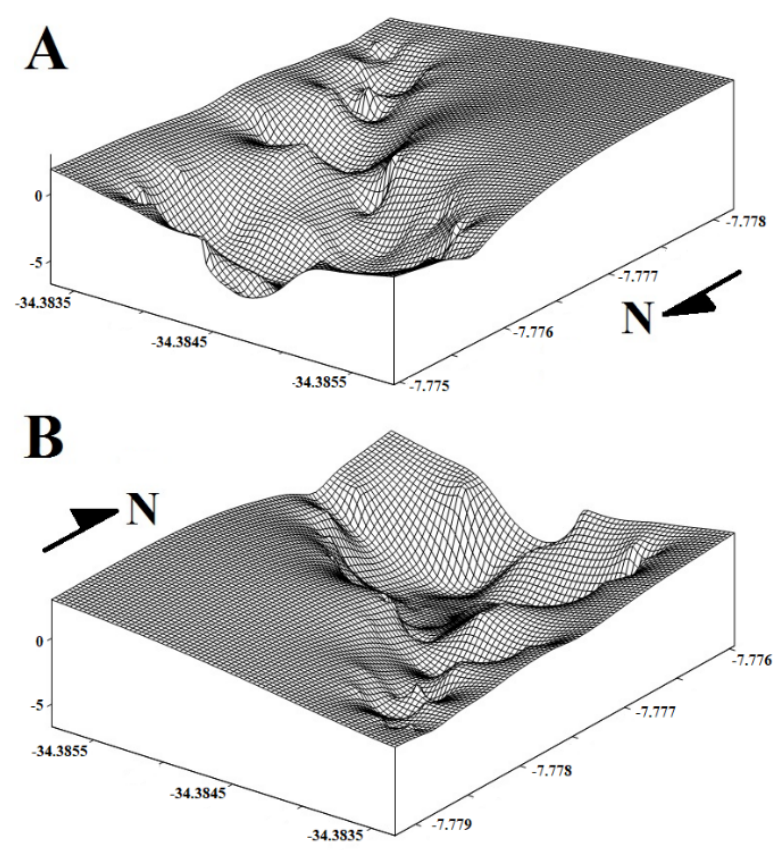

Figure 4 - Northwest (A) and southeast (B) three-dimensional views of Mata do Amparo Dam bathymetric profiles.

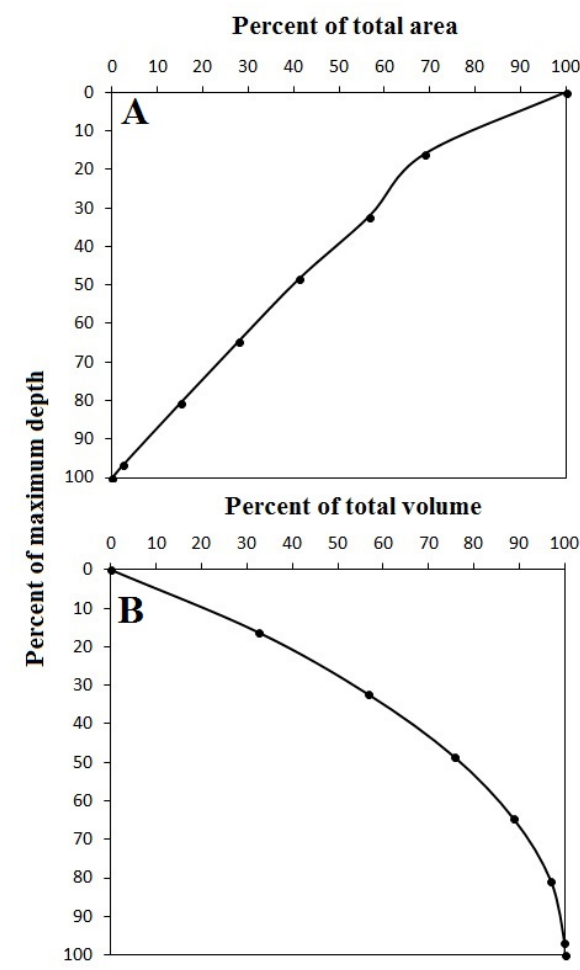

Figure 5 - Hypsographic curves of percent total surface (A) and percent total volume (B) in relation to percent maximum depth of Mata do Amparo Dam, Pernambuco State.. 


\section{DISCUSSION}

The estimated surface area of $0.042 \mathrm{~km}^{2}$ and volume of $0.11 \times 10^{6} \mathrm{~m}^{3}$ define Mata do Amparo Dam as a small lake $\left(\mathrm{A}<1 \mathrm{~km}^{2}\right)$, similar to several other artificial ponds and reservoirs found in Brazil (Table 3).

The number and distribution of transects, and number of depth points per square kilometer
$(8,857)$ used for generating the bathymetric chart seemed satisfactory for a detailed representation of bottom contour, as compared to similar surveys in Carioca Lake $\left(7,843\right.$ points. $\left.\mathrm{km}^{2}\right)$ (Bezerra-Neto et al., 2010) and Umari and Santa Cruz Reservoirs (respectively 1,812 and 1,895 points.km²) (Moura et al., 2015).

Table 3 - Morphometric parameters of selected Brazilian lacustrine environments. Abbreviations for parameters as in Table 1.

\begin{tabular}{|c|c|c|c|c|c|c|c|c|c|c|c|}
\hline \multirow{2}{*}{\multicolumn{2}{|c|}{ Environment }} & \multicolumn{10}{|c|}{ Morphometric parameters } \\
\hline & & $\begin{array}{c}\mathrm{A} \\
\left(\mathrm{km}^{2}\right)\end{array}$ & $\begin{array}{c}\mathbf{P} \\
(\mathbf{k m})\end{array}$ & $\begin{array}{c}\mathbf{L e} \\
(\mathbf{k m})\end{array}$ & $\begin{array}{c}\mathrm{We}_{\mathrm{e}} \\
(\mathbf{k m})\end{array}$ & $\begin{array}{c}\mathrm{V} \\
\left(10^{6} \mathrm{~m}^{3}\right)\end{array}$ & $\begin{array}{l}Z_{\max } \\
(\mathbf{k m})\end{array}$ & $\begin{array}{c}Z \\
(\mathrm{~m})\end{array}$ & $\begin{array}{c}Z_{r} \\
(\%)\end{array}$ & $\mathbf{D}_{\mathbf{s}}$ & $\mathbf{D}_{\mathbf{v}}$ \\
\hline \multirow{18}{*}{ 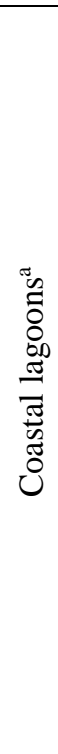 } & Gentil & 6.52 & 12.4 & 3.91 & 2.81 & 4.000 & 1.45 & 0.62 & 0.05 & 1.37 & - \\
\hline & Tapera & 0.74 & 3.3 & 1.03 & 0.98 & 0.700 & 2.12 & 0.89 & 0.22 & 1.07 & - \\
\hline & Prainha & 0.36 & 2.2 & 0.77 & 0.62 & 0.500 & 4.42 & 1.40 & 0.65 & 1.05 & - \\
\hline & Manuel Nunes & 2.91 & 7.4 & 2.62 & 1.78 & 2.700 & 1.96 & 0.91 & 0.10 & 1.23 & - \\
\hline & Fortaleza & 17.96 & 20.9 & 5.77 & 4.22 & 30.800 & 2.98 & 1.72 & 0.06 & 1.39 & - \\
\hline & Lessa & 0.71 & 3.2 & 1.15 & 0.89 & 0.800 & 1.80 & 1.06 & 0.19 & 1.08 & - \\
\hline & Suzana & 1.06 & 3.8 & 1.21 & 1.07 & 1.100 & 2.58 & 1.04 & 0.22 & 1.04 & - \\
\hline & Cidreira-Rondinha & 15.53 & 25.0 & 8.00 & 3.49 & 19.500 & 3.26 & 1.26 & 0.07 & 1.79 & - \\
\hline & \begin{tabular}{|l|} 
Cerquinha \\
\end{tabular} & 8.67 & 21.1 & 3.89 & 3.03 & 9.200 & 1.80 & 1.06 & 0.05 & 2.02 & - \\
\hline & Rincão das Éguas & 5.63 & 14.1 & 3.58 & 2.81 & 12.200 & 3.76 & 2.17 & 0.14 & 1.67 & - \\
\hline & Cipó & 2.36 & 9.3 & 2.25 & 1.69 & 2.400 & 2.08 & 1.02 & 0.12 & 1.70 & - \\
\hline & Lavagem & 0.75 & 3.3 & 1.19 & 0.92 & 1.000 & 2.61 & 1.38 & 0.27 & 1.06 & - \\
\hline & Porteira & 19.07 & 17.5 & 6.15 & 4.47 & 55.200 & 5.04 & 2.89 & 0.10 & 1.13 & - \\
\hline & Potreirinho & 2.23 & 5.5 & 1.90 & 1.69 & 3.600 & 2.91 & 1.62 & 0.17 & 1.04 & - \\
\hline & Capão Alto & 2.25 & 5.6 & 2.03 & 1.61 & 4.300 & 3.27 & 1.92 & 0.19 & 1.06 & - \\
\hline & Pinheiro & 0.64 & 3.6 & 1.14 & 0.72 & 1.400 & 6.35 & 2.23 & 0.70 & 1.27 & - \\
\hline & Quintão & 8.41 & 12.5 & 3.99 & 3.23 & 30.500 & 9.34 & 3.63 & 0.29 & 1.22 & - \\
\hline & Charqueada & 0.76 & 4.6 & 1.46 & 1.24 & 2.000 & 4.65 & 2.61 & 0.47 & 1.47 & - \\
\hline \multirow{7}{*}{ 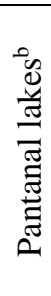 } & Buritizal & 4.02 & 7.7 & 2.67 & 2.23 & 12.900 & 4.20 & 2.72 & 0.19 & 1.07 & 1.94 \\
\hline & Coqueiro & 2.22 & 10.4 & 4.01 & 0.98 & 0.150 & 1.60 & 0.68 & 0.10 & 1.95 & 1.28 \\
\hline & Chacororé & 64.92 & 70.2 & 10.18 & 9.88 & 178.600 & 4.00 & 2.75 & 0.04 & 2.44 & 2.06 \\
\hline & \begin{tabular}{|l|} 
Pedras \\
\end{tabular} & 0.021 & 1.1 & 0.27 & 0.10 & 0.022 & 6.20 & 1.04 & 3.81 & 2.10 & 0.49 \\
\hline & Poço & 0.024 & 0.9 & 0.33 & 0.11 & 0.010 & 0.82 & 0.40 & 0.47 & 1.56 & 1.47 \\
\hline & Recreio & 0.75 & 4.1 & 1.48 & 0.94 & 0.990 & 2.30 & 1.32 & 0.24 & 1.31 & 1.72 \\
\hline & Sinhá Mariana & 11.25 & 36.5 & 8.75 & 2.67 & 40.400 & 4.75 & 3.58 & 0.13 & 3.05 & 2.26 \\
\hline \multirow{4}{*}{ 藏 } & Santa Cruz ${ }^{\mathrm{c}}$ & 18.90 & 94.8 & - & 4.16 & 295.800 & 37.97 & 13.50 & 0.77 & 6.14 & - \\
\hline & Umari $^{\mathrm{c}}$ & 14.60 & 110.9 & - & 3.42 & 114.900 & 27.01 & 8.18 & 0.63 & 8.17 & - \\
\hline & Hedberg $^{\mathrm{d}}$ & 0.23 & 3.9 & 0.78 & 0.45 & 0.500 & 5.58 & 2.90 & - & 2.28 & 1.56 \\
\hline & FEENA $^{\mathrm{e}}$ & 0.03 & 0.7 & 0.27 & 0.16 & 0.022 & 2.16 & 0.86 & 1.19 & 1.12 & 1.19 \\
\hline \multirow{3}{*}{ 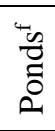 } & Saibro & 0.03 & 0.8 & 0.22 & 0.19 & 0.160 & 6.60 & 5.65 & 3.47 & 1.20 & 2.57 \\
\hline & Recreio & 0.08 & 1.3 & 0.42 & 0.28 & 0.170 & 4.50 & 2.26 & 1.44 & 1.27 & 1.50 \\
\hline & Pesqueiro & 0.008 & 0.5 & 0.14 & 0.10 & 0.015 & 3.50 & 1.96 & 3.52 & 1.44 & 1.68 \\
\hline \multirow{8}{*}{ 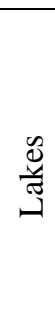 } & Lagoa Centralg & 1.700 & 6.5 & 1.96 & 1.57 & 6.800 & 6.86 & 3.89 & 0.50 & 1.38 & 1.70 \\
\hline & Carioca $^{\mathrm{h}}$ & 0.141 & 1.7 & 0.57 & 0.35 & 0.670 & 11.80 & 4.76 & 2.78 & 1.28 & 1.21 \\
\hline & Dom Helvécioi & 5.270 & 37.7 & 3.10 & 1.20 & 59.400 & 39.20 & 11.30 & 1.52 & 4.61 & 0.86 \\
\hline & Violãoj $^{j}$ & 0.270 & 2.8 & 1.10 & 0.50 & 1.814 & 10.50 & 6.60 & 1.80 & 1.40 & 1.90 \\
\hline & Amendoim $^{\mathrm{j}}$ & 0.130 & 1.7 & 0.60 & 0.30 & 0.489 & 8.00 & 3.90 & 2.00 & 1.40 & 1.40 \\
\hline & Três Irmãs $1^{j}$ & 0.070 & 1.3 & 0.50 & 0.20 & 0.188 & 3.90 & 2.50 & 1.30 & 1.30 & 1.90 \\
\hline & Três Irmãs $2^{\mathrm{j}}$ & 0.120 & 1.6 & 0.60 & 0.30 & 0.084 & 2.80 & 0.70 & 0.70 & 1.30 & 0.80 \\
\hline & Três Irmãs $3^{j}$ & 0.250 & 2.5 & 0.90 & 0.50 & 2.053 & 14.70 & 8.10 & 2.60 & 1.40 & 1.70 \\
\hline
\end{tabular}

References: a. Schäfer et al., 2014; Silva et al., 2018; b. Fantin-Cruz et al., 2008; c. Moura et al., 2015; d. Silva et al., 2016; e. Cicagna et al., 2014; f. Fernandes et al., 2014; g. Brighenti et al., 2011; h. Bezerra-Neto et al., 2010; i. BezerraNeto \& Pinto-Coelho, 2008; j. Silva et al., 2018.

The shape of a lake basin may be concave shape, which contribute to the exposure characterized by the volume development index of lake surface to wind action and vertical mixing (Dv). Lakes with Dv values $>1$ possess a (Wetzel, 2001; Tundisi \& Matsumura-Tundisi, 
2008), being predominant in Brazilian lakes and reservoirs (Table 3).

Such features also contribute to water vertical mixing and lake productivity (Brighenti et al., 2011; Moura et al., 2015), although productivity in Mata do Amparo Dam seems to be limited by low phosphorous and nitrogen concentrations (unpublished data).

Relative depth $\left(\mathrm{Z}_{\mathrm{r}}\right)$ and mean depth $(\mathrm{Z})$ in Mata do Amparo Dam (respectively, 2.68\% and $2.57 \mathrm{~m}$ ) are within the limits found in most Brazilian lacustrine environments (range 0.05$3.81 \%$, and $0.40-3.90 \mathrm{~m}$ ), as shown for selected environments summarized in Table $3 . \mathrm{Z}_{\mathrm{r}}$ values above $4 \%$ are only recorded in environments with maximum depth above $10 \mathrm{~m}$, such as Santa Cruz and Umari reservoirs (Moura et al., 2015) and lakes Carioca (Bezerra-Neto et al., 2010), Dom Helvécio (Bezerra-Neto \& Pinto Coelho, 2008), Violão and Três Irmãs 3 (Silva et al., 2018). $Z_{r}$ is another parameter that may influence thermal stability and limit vertical mixing (Wetzel \& Likens, 2000; Moura et al., 2015), and most lakes worldwide present low values $(<2 \%)$ as has also been recorded in Brazilian lakes and reservoirs (Table 3).

\section{CONCLUSIONS}

In spite of some limitations regarding the precision of the estimates of the morphometric variables of Mata do Amparo Dam, owing to the different equipment and sources used for data acquisition, the procedures used constitute an accessible low-cost method that may serve as a basis for comparative lake morphology studies with other lentic environments of similar size.

The morphometric characteristics presented in this paper have not been previously published for this environment, or any other natural or artificial lake in Pernambuco, and provide a physical background for future limnological research conducted on the site. Moreover, apart from being the largest freshwater lentic environment in Itamaracá Island, its location in the only perennial river basin of the island, the Jaguaribe river basin, makes the conservation of such environment of uttermost importance for future water supply and maintenance of the river flow. Future studies dedicated to understanding the limnological features of the reservoir should be encouraged, and the morphometric data herein provided might contribute to such endeavor.

\section{ACKNOWLEDGEMENTS}

The author thanks for the contribution of the undergraduate students of the discipline Limnology of the Fisheries Engineering course in field data sampling. Fundação Apolônio Salles de Desenvolvimento Educacional (FADURPE) is acknowledged for the financial support provided to field campaigns and equipment acquisition.

\section{REFERENCES}

AZEVEDO, L.S.P. Considerações geoquímicas das lagunas do litoral leste do Estuário do Rio de Janeiro. In. Lacerda, L.D.; Araújo, D.S.D.; Cerqueira, R.; Turcq, B. (Org.). Restingas: origem, estrutura, processos. Niterói: CEUFF, p. 453-458, 1984.

BEZERRA-NETO, J.F. \& PINTO-COELHO, R.M Morphometric study of Lake Dom Helvécio, Parque Estadual do Rio Doce (PERD), Minas Gerais, Brazil: a re-evaluation. Acta Limnologica Brasiliensia, v. 20, n. 2, p. 161-167, 2008. BEZERRA-NETO, J.F.; BRIGHENTI, L.S.; PINTO-COELHO, R.M. A new morphometric study of Carioca Lake, Parque Estadual do Rio Doce (PERD), Minas Gerais State, Brazil. Acta Scientiarum. Biological Sciences, v. 32, n. 1, p. 49-54, 2010.

BRANCO, S.M. \& ROCHA, A.A. Poluição, proteção e usos múltiplos de represas. São Paulo: Edgard Blucher. CETESB, 185p., 1977.

BRIGHENTI, L.S.; PINTO-COELHO, R.M.; BEZERRANETO, J.F.; GONZAGA, A.V. Parâmetros morfométricos da Lagoa Central (Lagoa Santa, Estado de Minas Gerais): comparação de duas metodologias. Acta Scientiarum. Biological Sciences, v. 33, n. 3, p. 281-287, 2011.

COMPANHIA DE PESQUISA DE RECURSOS MINERAIS. Projeto cadastro de fontes de abastecimento por água subterrânea. Diagnóstico do município de Ilha de Itamaracá, estado de Pernambuco. Recife: CPRM/PRODEEM, 10p., 2005.

FANTIN-CRUZ, I.; LOVERDE-OLIVEIRA, S.; GIRARD, P. Caracterização morfométrica e suas implicações na limnologia de lagoas do Pantanal Norte. Acta Scientiarum. Biological Sciences, v. 30, n. 2, p. 133-140, 2008.

GOLDEN SOFTWARE. Surfer 10 Quick -start guide. Colorado: Golden Software Inc. 50 p., 2011.

HUTCHINSON, G.E. A treatise on limnology. Vol. 1. Geography, physics and chemistry. New York: Wiley, 1015 p., 1957.

JOHANSSON, H.; BROLIN, A.A.; HAKANSON, L. New approaches to the modelling of lake basin morphometry. Environmental Modelling \& Assessment, v. 12, n. 3, p. 213228, 2007.

KÖPPEN, W. 1936. Handbuch der Klimatologie In: W. Köppen, R. Geiger. C-1-C-44, Gebruder Borntraeger, Berlin. [online] URL: $\quad$ http://koeppen-geiger.vuwien.ac.at/pdf/Koppen_1936.pdf. Access in 25 Jul. 2018.

MOURA, R.S.T.; SANTOS, R.F.; LOPES, Y.V.A.; HENRYSILVA, G.G. Parâmetros morfométricos dos reservatórios Santa Cruz e Umari, semiárido do Rio Grande do Norte, Brasil. Boletim do Instituto de Pesca, v. 41, n. 2, p. 355-363, 2015. 
PEREIRA, G.A.; COELHO, G.; DANTAS, S.M.; RODA, S.A.; FARIAS, G.B.; PERIQUITO, M.C.; BRITO, M.T.; PACHECO, G.L. Ocorrências e hábitos alimentares do falcãoperegrino Falco peregrinus no Estado de Pernambuco. Brasil. Revista Brasileira de Ornitologia, v. 14. n. 27. p. 435-439, 2006.

SANTOS, J.L. A construção do discurso de modernidade: análise do cotidiano de operários e detentos da Penitenciária Agrícola de Itamaracá entre 1938 e 1962. Anais do V Colóquio de História, Recife, p. 99-111. 2011.

SCHÄFER, A.; MARCHETT, C.A.; SCHUH, S.M.; AHLERT, S.; LANZER, R.M. Morphological characterization of eighteen lakes of the north and middle coast of Rio Grande do Sul, Brazil. Acta Limnologica Brasiliensia, v. 26, n. 2, p. 199-214, 2014.

SCHWARZBOLD, A. \& SCHÄFER, A. Gênese e morfologia das lagoas costeiras do Rio Grande do Sul - Brasil. Amazoniana, v. 9, n. 1, p. 87-104, 1984.

SILVA, D.C.C.; SALES, J.C.A.; ALBUQUERQUE FILHO, J.L.; LOURENÇO, R.W. Características morfométricas e suas implicações no acúmulo de sedimentos em reservatórios: o caso da Represa Hedberg, Iperó/SP. Revista Ra'e Ga, v. 36, p. 225245, 2016.

SILVA, M.S.; GUIMARÃES, J.T.F.; SOUZA FILHO, P.W.M.; NASCIMENTO JÚNIOR, W.; SAHOO, P.K.; COSTA, F.R.; SILVA JÚNIOR, R.O.; RODRIGUES, T.M.; COSTA, M.F. Morphology and morphometry of upland lakes over lateritic crust, Serra dos Carajás, southeastern Amazon region. Anais da Academia Brasileira de Ciências, v. 90, n. 2, p. 1309-1325, 2018.
TUNDISI, J.G. \& MATSUMURA-TUNDISI, T. Limnologia São Paulo: Oficina de Textos, 631p., 2008.

TUNDISI, J.G. \& MUSARRA, M.L. Morphometry of four lakes in the Rio Doce Valley lake system and its relationship with primary production of phytoplankton. Revista Brasileira de Biologia, v. 46. n. 1. p. 159-171, 1986.

TUNDISI, J.G. Água no Século XXI: enfrentando a escassez. São Carlos: RiMa. IIE, 248 p., 2003.

WETZEL, R.G. \& LIKENS, G.E. Limnological analyses. 3rd ed. New York: Springer, 429 p., 2001.

WETZEL, R.G. Limnology: lakes and river ecosystems. 3rd ed.. San Diego: Academic Press, 1006 p., 2001.
Submetido em 8 de janeiro de 2019 Aceito para publicação em 5 de agosto de 2020 